\title{
IMPACTS OF LEAF AREA ON THE PHYSIOLOGICAL ACTIVITY AND BERRY MATURATION OF MERLOT (VITIS VINIFERA L.)
}

\author{
CANDAR, S. ${ }^{1}-$ BAHAR, $^{2}{ }^{2}-$ KORKUTAL, I. ${ }^{2 *}$ \\ ${ }^{I}$ Tekirdag Viticulture Research Institute, Tekirdag, Turkey \\ ${ }^{2}$ Department of Horticulture, Agricultural Faculty, Tekirdag Namik Kemal University \\ 59030 Tekirdag, Turkey \\ ${ }^{*}$ Corresponding author \\ e-mail: ikorkutal@nku.edu.tr;+90-282-250-2059 \\ (Received 26 $6^{\text {th }}$ Sep 2019; accepted $8^{\text {th }}$ Jan 2020)
}

\begin{abstract}
The aim of this research was to understand some physiological and agronomical behaviors of the Merlot grapevine subjected to different canopy management practices under the climatic conditions of different growing seasons in Tekirdag, Turkey. The resulting must composition and berry maturation were also determined. Adult vines of Vitis vinifera L. cv. Merlot, grafted onto 5BB were applied to different leaf areas (various levels of leaf removal from main and lateral shoots) during the growing season. Leaf photosynthesis (A) and transpiration (E), stomatal conductance $\left(\mathrm{g}_{\mathrm{s}}\right)$, yield parameters, maturation indices and berry composition at harvest were analyzed over a period of three consecutive years between 2013 and 2015. In the vegetation periods of 2013 and 2015 when there is less precipitation, proportional humidity is relatively low and temperatures are high, positive results were obtained in terms of quality criteria in half lateral shoots (3-4 leaves= HLS) application. Under extreme rainfall and high relative humidity conditions as in 2014, none lateral shoots (NLS) application increased physiological activity and relative quality. The main factor controlling the physiological behavior and grape ripening in Merlot vines was largely dependent on the meso-climatic conditions during the growing season. However, the total effect of small differences in the canopy microclimates created by different leaf area reduction applications affected the indicators of industrial maturity at the end of vegetation. Planning of canopy management practices should be done by taking into consideration long- and medium-term meteorological evaluations, and short-term planning within vegetation should be considered by weighing weekly and monthly meteorological risks.
\end{abstract}

Keywords: canopy management, green pruning, climate, leaf gas exchange, quality

\section{Introduction}

Climate, especially temperature is the major component of wine grape terroirs, with a number of other factors including soil characteristics and soil water reserves, grape variety and rootstock, cultivation techniques such as cover crops and leaf fruit ratio. Grape berry maturation is generally associated with all of these factors.

The negative effects of the current climate crisis are getting worse every year. Early and accelerated berry ripening (Petrie and Sadras, 2008; Keller, 2010a), changing of usual wine styles due to unexpected seasonal precipitation (Mira de Orduña, 2010; Schultz and Stoll, 2010), problems like higher alcohol ratios with lower acidity and reduced varietal aroma compounds due to high sugar in berries (Keller, 2010a) are the troubles that stand out to be solved by winemakers. It is very important for the wine industry to adapt to alternative viticulture and winemaking methods to get used to these new climatic conditions (Clingeleffer, 2010). As Carbonneau and Bahar (2009) stated global warming is inevitable, a couple of new strategies should be tried like breeding of new varieties and rootstocks, soil management and more important for short term vine 
canopy management for sustainable viticulture. Canopy management treatments, such as pruning, trimming and leaf removal, can be certainly utilize to organize vine source-sink balance (Santesteban et al., 2011; Moran et al., 2017). There are a lot of researches indicating that the early maturation or postponement of the industrial maturity may occur when the leaf removal is applied in the proper style and time (Poni et al., 2013; Caccavello et al., 2017).

Another factor which is as effective as the climate in determining berry maturity is the genetic infrastructure of the variety that determines the physiological activity. Young leaves generally start to produce excess photo assimilates, translocated afterwards to the other parts of the vine after they reach one third of their full sizes, approximately 5 or 6 weeks after leaf unfolding (Keller, 2010b). As the leaves age, their photosynthetic capacity and their contribution to organic matter production increase to some point, then fall. Depending on leaf age, regardless of whether they come from the lateral or main shoot, individual photosynthetic activities are effective in berry ripening and in sugar accumulation in grape juice (Hirano et al., 1994). Due to this phenomenon it is important to point out the role of leaf removal practices about ripening processes. The lack of proper canopy management promotes the occurrence of unbalanced vineyards with intense vegetative growth (Zalamena et al., 2013; Bem et al., 2016) and results unbalanced wines.

The aim of the study was to have a better understanding about the impact of leaf removal practices on physiological activities and berry maturation of grapes under the monitored climate conditions.

\section{Materials and Methods}

\section{Location, vine material and experimental set-up}

The experimental study was conducted in 2013, 2014 and 2015 in an experimental vineyard, in Tekirdağ Viticulture Research Institute, Turkey $\left(40.96{ }^{\circ} \mathrm{N}-40.97{ }^{\circ} \mathrm{N}\right.$ latitudes, $27.46^{\circ} \mathrm{E}-27.47^{\circ} \mathrm{E}$ longitudes) with Vitis vinifera $\mathrm{cv}$. Merlot which is grown in large quantities in the Thrace region and preferred because it has high adaptability to the region climate and gives high wine quality. However, Merlot which showed more anisohydric characters (Collins and Loveys, 2010).

The grapevines, grafted on 5BB rootstock were 14 years old. Double Guyot training vines loaded 16-18 buds per vine, with distances of $2.5 \mathrm{~m}$ between rows and $1.5 \mathrm{~m}$ between plants. The vineyard is planted on North-South at $40 \mathrm{~m}$ altitude on a high groundwater and, flat land with no significant soil variations. Analyses in 0-90 cm soil depth observed that in the clay-loam structure, slightly alkaline and calcareous, in at a depth of $60-90 \mathrm{~cm}$ highly calcareous with no salinity problem. Agrotechnical applications were done 3 consecutive years which were given Table 1. All plant protection procedures were done routinely in vineyard.

Different leaf areas of vines were created by the limitations of main shoot lengths $1 \mathrm{~m}, 1.25 \mathrm{~m}$ and $1.5 \mathrm{~m}$ while they reached $170-180 \mathrm{~cm}$ (EL 31-33). Lateral shoots also limited as full lateral shoots (6-7 leaves: FLS), half lateral shoots (3-4 leaves: HLS) and none lateral shoots (no leaf: NLS) performed in veraison (Eichhorn-Lorenz growing stages 35) according to Lorenz et al. (1995). Both applications were kept at the same length until the harvest period.

Descriptive meso-climatic weather data such as temperature, relative humidity, light intensity, wind speed and total precipitation at two meters high from ground were 
monitored during for 3 consecutive years with a weather station installed within the experimental area (Table 2).

Table 1. Agrotechnical applications and dates in years of 2013, 2014 and 2015

\begin{tabular}{|c|c|c|c|c|}
\hline Applications & 2013 & 2014 & 2015 & EL stages \\
\hline Equalization of buds & 06.03 .2013 & 15.03 .2014 & $\begin{array}{l}09.03 .2015 \\
10.03 .2015\end{array}$ & $\begin{array}{l}16 \text { buds } \\
\text { (EL 5-7) }\end{array}$ \\
\hline Equalization of shoots & 07.05 .2013 & $\begin{array}{l}15.05 .2014 \\
20.05 .2014\end{array}$ & $\begin{array}{l}14.05 .2015 \\
15.05 .2015 \\
\end{array}$ & $\begin{array}{l}30-40 \mathrm{~cm} \text { shoot lenght } \\
\text { (EL 12-15-17) }\end{array}$ \\
\hline Equalization of cluster numbers & $\begin{array}{l}18.06 .2013 \\
19.06 .2013\end{array}$ & $\begin{array}{l}18.06 .2014 \\
19.06 .2014\end{array}$ & 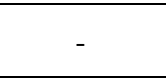 & Clusters visible (EL 15-17). \\
\hline Topping & $\begin{array}{l}01.07 .2013 \\
03.07 .2013 \\
\end{array}$ & $\begin{array}{l}19.06 .2014 \\
23.06 .2014 \\
\end{array}$ & $\begin{array}{l}22.06 .2015 \\
26.06 .2015 \\
\end{array}$ & $\begin{array}{l}170-180 \mathrm{~cm} \text { main shoot length } \\
(\text { EL 31-33) }\end{array}$ \\
\hline Lateral shoot removal & $\begin{array}{l}08.07 .2013 \\
10.07 .2013\end{array}$ & $\begin{array}{l}28.07 .2014 \\
01.08 .2014\end{array}$ & $\begin{array}{l}27.07 .2015 \\
05.08 .2015\end{array}$ & $\begin{array}{l}\text { Veraison and post veraison } \\
\text { (EL 35) }\end{array}$ \\
\hline Control of top and lateral shoots & $\begin{array}{l}22.07 .2013 \\
05.08 .2013\end{array}$ & $\begin{array}{l}21.08 .2014 \\
22.08 .2014 \\
01.09 .2014 \\
02.09 .2014 \\
08.09 .2014 \\
09.09 .2014\end{array}$ & $\begin{array}{l}24.08 .2015 \\
28.08 .2015\end{array}$ & \\
\hline
\end{tabular}

Table 2. The climatic data of Tekirdag during the vegetation period in years of 2013, 2014 and 2015

\begin{tabular}{c|c|c|c|c|c|c}
\hline Years & Months & $\begin{array}{c}\text { Mean Temp. } \\
\left({ }^{\circ} \mathbf{C}\right)\end{array}$ & $\begin{array}{c}\text { Precipitation } \\
(\mathbf{m m})\end{array}$ & $\begin{array}{c}\text { Relative } \\
\text { humidity } \mathbf{( \% )}\end{array}$ & $\begin{array}{c}\text { Wind speed. } \\
\left(\mathbf{m ~ s}^{\mathbf{- 1}}\right)\end{array}$ & $\begin{array}{c}\text { Light } \\
\text { intensity } \\
\left(\boldsymbol{\mu} \mathbf{m o l}_{\mathbf{~}} \mathbf{s}^{\mathbf{1}}\right)\end{array}$ \\
\hline \multirow{6}{*}{2013} & April & 13.50 & 16.00 & 84.80 & 2.20 & 1026.82 \\
& May & 19.50 & 8.00 & 69.70 & 2.40 & 1244.67 \\
& June & 22.40 & 35.00 & 68.70 & 2.60 & 1189.14 \\
& July & 24.70 & 0.00 & 61.40 & 3.20 & 1307.08 \\
& August & 25.90 & 0.00 & 62.30 & 3.50 & 1128.17 \\
& September & 21.60 & 10.20 & 61.40 & 2.60 & 854.82 \\
& October & 14.30 & 96.40 & 76.20 & 2.30 & 573.62 \\
\hline \multirow{6}{*}{2014} & April & 13.37 & 46.80 & 83.27 & 2.43 & 408.98 \\
& May & 17.53 & 72.10 & 80.29 & 2.36 & 560.41 \\
& June & 21.8 & 69.6 & 76.2 & No data & No data \\
& July & 24.81 & 107.70 & 73.03 & 2.50 & 800.19 \\
& August & 25.28 & 80.50 & 74.52 & 2.72 & 1154.46 \\
& September & 20.77 & 98.50 & 77.90 & 2.58 & 1027.51 \\
& October & 15.61 & 136.10 & 79.84 & 2.92 & 684.94 \\
\hline \multirow{6}{*}{2015} & April & 11.4 & 58.6 & 74.3 & 2.8 & 1179.36 \\
& May & 18.6 & 32.0 & 76.3 & 2.5 & 1172.86 \\
& June & 21.3 & 63.6 & 73.3 & 2.8 & 1167.01 \\
& July & 24.9 & 1.8 & 70.6 & 3.0 & 1760.77 \\
& August & 26.1 & 1.6 & 68.9 & 3.3 & 1289.66 \\
& September & 22.7 & 29.8 & 77.2 & 2.7 & 891.70 \\
& October & 16.4 & 80.4 & 80.1 & 3.2 & 621.58 \\
\hline
\end{tabular}

Despite the equal number of (16) buds left in the winter pruning, the plants that disrupt homogeneity in the number of shoots and bunches were balanced when the shoots reached an average length of 30-40 cm (EL 15-17) or excluded from the trial. Standard cultural practices in the region were applied to all treatments during research. The vines data taken were selected from the same development period and with the approximate charge and those without spaces. 


\section{Total leaf area and leaf area per $\mathrm{kg}$ of grapes}

Leaf areas of each application were calculated by, multiplying the number of shoots per vine and the number of leaves per shoot which were scanned with CI-202 Portable Laser Leaf Area Meter (CID Bio-Science, Washington, USA), from four shoots in each vine of every application.

Ratio of total leaf area $\left(\mathrm{m}^{2}\right.$ vine $\left.^{-1}\right)$ to yield $\left(\mathrm{kg}_{\text {vine }}{ }^{-1}\right)$ was calculated for determining leaf area per kg of grapes according to Sanchez-de-Miguel et al. (2010).

\section{Leaf gas exchange measurements}

Leaf gas exchange [net photosynthesis $\left(\mathrm{A}, \mu \mathrm{mol} \mathrm{CO}_{2} \mathrm{~m}^{-2} \mathrm{~s}^{-1}\right)$ and transpiration $(\mathrm{E}$,

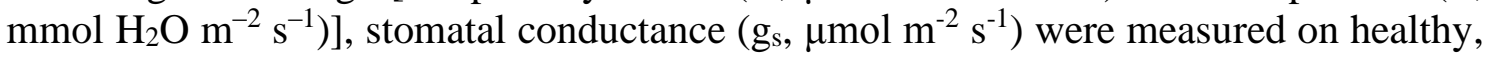
fully expanded, mature and non-senescent leaves by using LI-6400XT (Li-Cor Inc., Nebraska, USA) portable photosynthesis system, between 10:00-12:00 AM. During the measurements, the device was calibrated to $400 \mu \mathrm{mol} \mathrm{CO} \mathrm{Cm}^{-2} \mathrm{~s}^{-1}$ atmospheric $\mathrm{CO}_{2}$ and $25^{\circ} \mathrm{C}$ block temperature. In each application, 10 measurements were performed on one leaf of each of the four grapevines, and these measurements were used as the average of repetitions.

\section{Must composition and berry maturation}

At harvest, two hundred berries per replicate were selected to determine primary juice compounds as total soluble solids (\%, TSS; $\left.{ }^{\circ} \mathrm{Brix}\right)$ with handheld refractometer (ATAGO Co. Ltd., Tokyo, Japan), pH with digital pH meter (Mettler Toledo FE20. Switzerland), total acidity ( $\mathrm{g} \mathrm{L}^{-1}$ of tartaric acid) in must at the harvest date using the official methods of the Organisation Internationale de la Vigne et du Vin (OIV, 2012).

In addition, the amount of sugar per gram of grapes $\left(\mathrm{mg} \mathrm{g}\right.$-berry $\left.^{-1}\right)$ was calculated by dividing the amount of sugar in the berry by the fresh weight (Ferrer et al., 2014). Maturity indicators; ${ }^{\circ}$ Brix/titratable acid, and $\mathrm{pH}^{2} \times{ }^{\circ}$ Brix values were calculated and evaluated according to Blouin and Guimberteau (2000).

\section{Statistical analysis}

Results were subjected to variance analysis with JMP 13.2.0 statistical software according to split-plots trail design for determining of differences in applications and years. LSD test was used at 5\% significance level to identify differences between significant means.

\section{Results and Discussion}

\section{Climatic conditions and grapevine phenology}

In the 3 years that the study was carried out, 2014 was distinguished from 2013 and 2015 in terms of temperature and especially precipitation amount, as well as climatic characteristics such as light intensity, relative humidity and wind speed. While the mean of total annual precipitation for the 1939-2018 period is $582.90 \mathrm{~mm}$; the total precipitation was $443.80 \mathrm{~mm}$ in 2013, $770.50 \mathrm{~mm}$ in 2014 and $507.90 \mathrm{~mm}$ in 2015 (Table 2).

As a result of the phenological observations made throughout the trial, the day green shoot tips seen clearly in the buds was 05.04.2013 in 2013 ( $94^{\text {th }}$ calendar day), 
02.04.2014 ( $91^{\text {st }}$ calendar day) for the year 2014, for 2015 it was observed as 12.04.2015 (101 ${ }^{\text {st }}$ calendar day). The date of the veraison was determined as 22.07.2013 $\left(202^{\text {th }}\right.$ calendar day) for the year $2013,30.07 .2014\left(210^{\text {th }}\right.$ calendar day $)$ for the year 2014 and 01.08 .2015 ( $212^{\text {th }}$ calendar day) for the year 2015. Harvest was done at \%22-23 TSS excluding 2014. It was held on 26.08.2013 (237 th calendar day) in 2013, 16.09.2014 ( $258^{\text {th }}$ calendar day) in 2014 and 05.10.2015 ( $277^{\text {th }}$ calendar day) in 2015.

Climatic data were also recorded on the days of physiological activity measurement at 10.00-12.00 during the experiment (Table 3).

Table 3. The climatic data of physiological activity measurement days in years of 2013, 2014 and 2015

\begin{tabular}{|c|c|c|c|c|c|c|c|}
\hline Dates & $\begin{array}{c}\text { Calendar } \\
\text { days }\end{array}$ & $\begin{array}{c}\text { Mean temp. } \\
\left({ }^{\circ} \mathrm{C}\right)\end{array}$ & $\begin{array}{l}\text { Max. temp. } \\
\quad\left({ }^{\circ} \mathrm{C}\right)\end{array}$ & $\begin{array}{c}\text { Min. temp. } \\
\left({ }^{\circ} \mathrm{C}\right)\end{array}$ & $\begin{array}{l}\text { Wind } \\
\text { speed } \\
\left(\mathrm{m} \mathrm{s}^{-1}\right)\end{array}$ & $\begin{array}{c}\text { Relative } \\
\text { humidity } \\
(\%)\end{array}$ & $\begin{array}{l}\text { Light intensity } \\
\left(\mu \mathrm{mol} \mathrm{m^{2 }} \mathrm{s}^{-1}\right)\end{array}$ \\
\hline 11.06 .2013 & 161 & 23.46 & 27.70 & 17.30 & 1.70 & 73.90 & 1466.47 \\
\hline 04.07 .2013 & 184 & 24.56 & 25.20 & 16.30 & 1.65 & 53.00 & 1202.07 \\
\hline 12.07 .2013 & 192 & 27.73 & 28.30 & 19.40 & 1.90 & 52.00 & 1559.96 \\
\hline 26.07 .2013 & 206 & 28.65 & 28.90 & 19.70 & 1.85 & 37.70 & 1496.46 \\
\hline 31.07 .2013 & 211 & 27.58 & 29.30 & 23.10 & 2.90 & 59.00 & 966.06 \\
\hline 15.08 .2013 & 226 & 28.37 & 31.50 & 23.20 & 3.00 & 60.80 & 1063.89 \\
\hline 27.08 .2013 & 238 & 25.17 & 29.10 & 18.80 & 1.70 & 79.80 & 1293.80 \\
\hline 24.06 .2014 & 174 & 23.69 & 28.12 & 18.68 & 2.54 & 70.37 & 1163.02 \\
\hline 01.07 .2014 & 181 & 23.30 & 26.50 & 18.20 & 2.10 & 78.00 & 723.24 \\
\hline 08.07 .2014 & 188 & 24.70 & 29.30 & 19.30 & 2.30 & 65.00 & 1144.04 \\
\hline 15.07 .2014 & 195 & 25.30 & 30.20 & 20.10 & 3.50 & 73.00 & 725.67 \\
\hline 19.08 .2014 & 230 & 23.60 & 28.30 & 17.90 & 3.60 & 66.00 & 1318.75 \\
\hline 26.08 .2014 & 237 & 25.00 & 29.90 & 20.40 & 3.10 & 72.00 & 1743.94 \\
\hline 02.09 .2014 & 244 & 24.00 & 28.30 & 19.90 & 2.10 & 80.00 & 1496.11 \\
\hline 07.07 .2015 & 187 & 24.60 & 29.50 & 18.40 & 2.30 & 70.10 & 1902.26 \\
\hline 21.07 .2015 & 201 & 25.00 & 31.10 & 18.40 & 2.80 & 74.20 & 1841.68 \\
\hline 28.07 .2015 & 208 & 27.70 & 32.30 & 21.80 & 1.70 & 69.30 & 1677.26 \\
\hline 04.08 .2015 & 215 & 26.50 & 30.20 & 21.70 & 2.20 & 76.20 & 1894.88 \\
\hline 11.08 .2015 & 222 & 25.90 & 29.40 & 21.00 & 2.90 & 74.50 & 1589.56 \\
\hline 18.08 .2015 & 229 & 27.30 & 32.00 & 22.80 & 3.30 & 74.90 & 1159.53 \\
\hline 25.08.2015 & 236 & 25.50 & 30.40 & 19.80 & 4.30 & 61.40 & 1583.40 \\
\hline 11.09.2015 & 253 & 25.20 & 29.20 & 22.20 & 2.80 & 82.40 & 939.32 \\
\hline 02.10 .2015 & 274 & 16.30 & 19.90 & 13.00 & 3.20 & 77.30 & 44.37 \\
\hline
\end{tabular}

\section{Yield (kg vine-1)}

In both years, 16 buds per vine were left in winter pruning, and shoots and clusters were equalized when the shoots reached $30-40 \mathrm{~cm}$ length. Thus, the differences between the yield values were not statistically significant. Yield values were seen the lowest for NLS application with $4.60 \mathrm{~kg}$ vine $^{-1}$ and highest for FLS application with $5.00 \mathrm{~kg}$ vine $^{-1}$.

Due to 16 buds per vine were left in winter pruning and the equalization of shoots and clusters, in every three years the differences between the yield values were not statistically significant and ranged between $5.20 \mathrm{~kg}$ vine $^{-1}$ and $5.43 \mathrm{~kg}$ vine $^{-1}$. The lowest yield was seen for $1 \mathrm{~m}$ main shoot length and the highest were seen for $1.5 \mathrm{~m}$ main shoot length treatment for the mean of years.

\section{Total leaf area and leaf area per $\mathrm{kg}$ of grapes $\left(\mathrm{m}^{2}\right.$ vine $\left.^{-1}\right)$}

In accordance with the method, different total leaf areas and different canopy microclimates were tried to be created in each year. The result that the interventions on 
the total leaf areas per vine were found to be statistically significant when the mean of the three years and were each year individually, showed that the desired different canopy architecture and differentiation of the canopies were achieved (Table 4).

Table 4. Effects of main shoot and lateral shoot treatments on total leaf area ( $\mathrm{m}^{2}$ per vine) and leaf area $\left(m^{2}\right.$ per $\mathrm{kg}$ grape $)$

\begin{tabular}{|c|c|c|c|c|c|c|c|c|}
\hline & \multicolumn{2}{|c|}{2013} & \multicolumn{2}{|c|}{2014} & \multicolumn{2}{|c|}{2015} & \multicolumn{2}{|c|}{ Mean of years } \\
\hline Treatments & $\begin{array}{c}\text { TLA } \\
\left(\mathrm{m}^{2} \text { per }\right. \\
\text { vine }) \\
\end{array}$ & $\begin{array}{c}\text { LA } \\
\left(\mathrm{m}^{2} \text { per kg }\right. \\
\text { grape) }\end{array}$ & $\begin{array}{c}\text { TLA } \\
\left(\mathrm{m}^{2} \text { per }\right. \\
\text { vine })\end{array}$ & $\begin{array}{c}\text { LA } \\
\left(\mathrm{m}^{2} \text { per kg }\right. \\
\text { grape }) \\
\end{array}$ & $\begin{array}{c}\text { TLA } \\
\left(\mathrm{m}^{2} \text { per }\right. \\
\text { vine })\end{array}$ & $\begin{array}{c}\text { LA } \\
\left(\mathrm{m}^{2} \text { per } \mathrm{kg}\right. \\
\text { grape }) \\
\end{array}$ & $\begin{array}{c}\text { TLA } \\
\left(\mathrm{m}^{2} \text { per }\right. \\
\text { vine })\end{array}$ & $\begin{array}{c}\text { LA } \\
\left(\mathrm{m}^{2} \text { per kg }\right. \\
\text { grape) } \\
\end{array}$ \\
\hline $1 \mathrm{~m}$ & $4.55 b$ & $0.73 b$ & 3.50 & 5.55 & 4.10 & 0.46 & $4.05 b$ & 2.25 \\
\hline $1.25 \mathrm{~m}$ & $4.66 b$ & $0.76 b$ & 3.94 & 6.39 & 4.22 & 0.46 & $4.27 b$ & 2.54 \\
\hline $1.5 \mathrm{~m}$ & $5.43 a$ & $0.89 a$ & 4.41 & 7.25 & 4.72 & 0.51 & $4.85 a$ & 2.88 \\
\hline NLS & $2.10 c$ & $0.33 c$ & $1.79 c$ & $2.89 c$ & $1.83 c$ & $0.21 c$ & $1.92 c$ & $1.14 c$ \\
\hline HLS & $5.70 b$ & $0.92 b$ & $3.95 b$ & $6.23 b$ & $4.55 b$ & $0.51 b$ & $4.73 b$ & $2.55 b$ \\
\hline FLS & $6.83 a$ & $1.14 a$ & $6.11 a$ & $10.08 a$ & $6.67 a$ & $0.71 a$ & $6.54 a$ & $3.98 a$ \\
\hline YME & $4.88 A$ & $0.79 B$ & $3.95 B$ & $6.40 A$ & $4.35 B$ & $0.48 B$ & & \\
\hline MSME LSD 0.05 & 0.412 & 0.151 & n.s. & n.s. & n.s. & n.s. & 0.282 & n.s. \\
\hline${ }_{L S M E} L S D_{0.05}$ & 0.554 & 0.083 & 0.729 & 1.738 & 0.453 & 0.045 & 0.401 & 0.432 \\
\hline$Y M E L S D_{0.05}$ & 0.401 & 0.432 & 0.401 & 0.432 & 0.401 & 0.432 & & \\
\hline
\end{tabular}

TLA and LA represent total leaf area $\left(\mathrm{m}^{2}\right.$ per vine) and leaf area $\left(\mathrm{m}^{2}\right.$ per $\mathrm{kg}$ grape). NLS, HLS, and FLS represent none lateral shoots (no leaf), half lateral shoots (3-4 leaves) full lateral shoots (6-7 leaves), MSME means main shoot main effect, LSME means lateral shoot main effect and YME means year main effect. Different lowercase superscript letters in same column and uppercase letters in same line represent statistically significant differences between means at $p<0.05$ according to least significant difference test. n.s. means not significant

Values for leaf area per $\mathrm{kg}$ of grapes resulting from unusually low yields in 2014, due to severe Plasmopara viticola epidemic caused extraordinary rainfall, increased average values for both lateral and main shoot treatments. When the year 2014 is ignored, it is seen that $0.73 \mathrm{~m}^{2}$ leaf area for $\mathrm{kg}_{\text {grape }}{ }^{-1}$ of vine for $1 \mathrm{~m}$ main shoot length for 2013 year is sufficient and statistically significant. Also, lateral shoot treatments were found statistically significant in terms of each year and mean of years (Table 4).

In our study, it is seen that the targeted yield can be achieved, without quality loss, with some delay in industrial maturity even when the leaf areas are reduced more than regional standards. Therefore, it is considered that the decrease in leaf areas can be compensated for in terms of yield by arrangements in the internal metabolism of the vine. This shows that unusual canopy management practices that can be applied against unusual climatic conditions (high relative humidity, high temperature fluctuations, extreme rainy periods, etc.) can be used in certain periods, but not every year. However, to obtain the quality and optimum yield without excessive vegetative growth, interventions to the clusters and canopy should be considered carefully in order to optimize the leaf/crop ratio at different stages of development.

\section{Net photosynthesis (A). transpiration (E) and stomatal conductance ( $\left.g_{s}\right)$ measurements}

When the measurement days are examined one by one in 2013; it is seen that photosynthesis (A) values vary between $18.03-7.62 \mu \mathrm{mol} \mathrm{CO}_{2} \mathrm{~m}^{-2} \mathrm{~s}^{-1}$. HLS showed the highest rate of photosynthesis (A) in 4 of 7 days. In terms of main shoot lengths, $1.25 \mathrm{~m}$ treatment showed the highest rates of photosynthesis in 4 of 7 days. As can be seen in 
Figure 1 transpiration (E) measurements also show parallelism with photosynthesis (A) rates. In general, the highest transpiration rates were observed in the measurements performed in July. Although there were no significant differences between the applications, highest transpiration values were measured in NLS and $1.25 \mathrm{~m}$ applications after the completion of the lateral shoot applications and the creation of the desired leaf area formations.
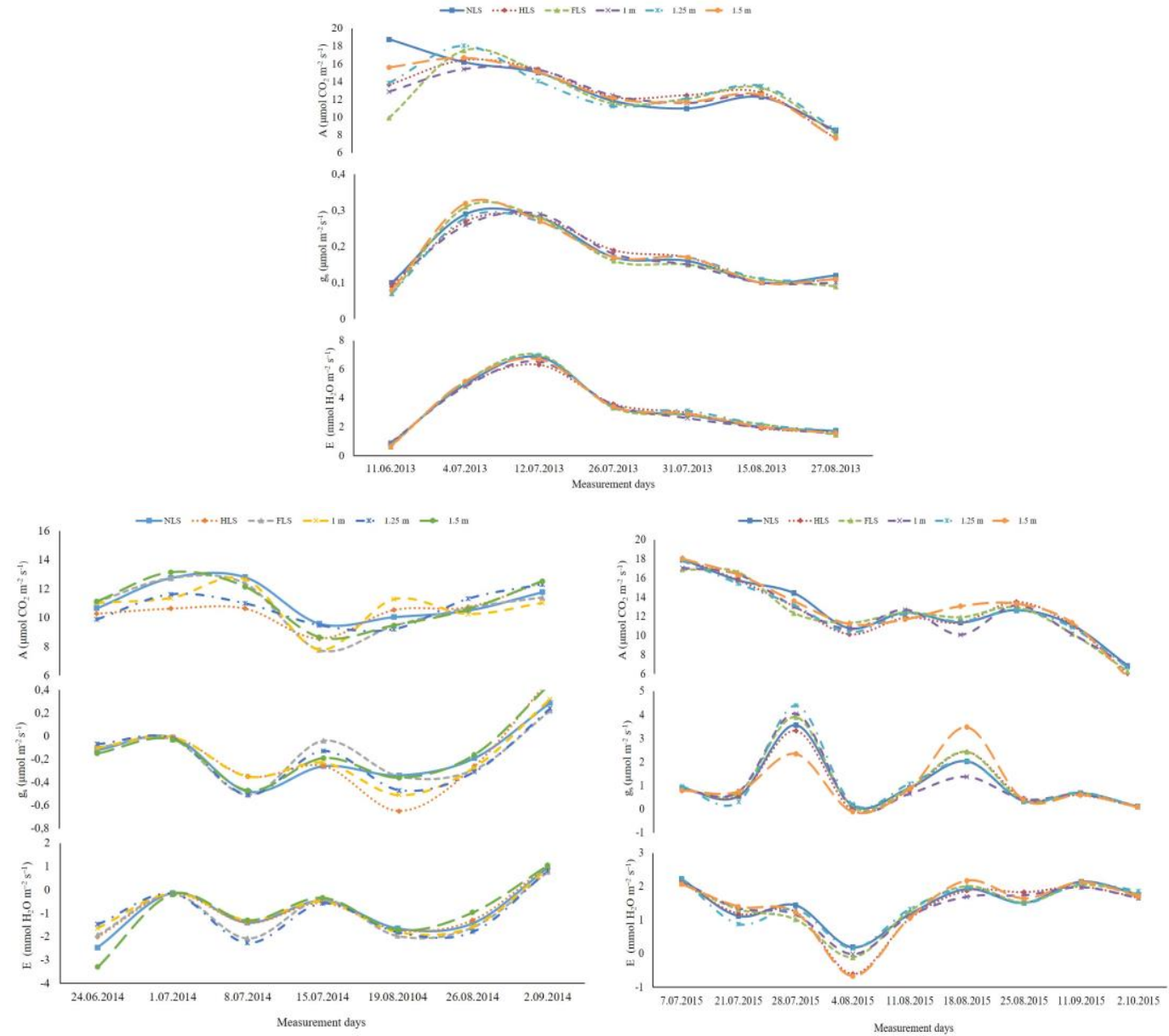

Figure 1. Net photosynthesis $(A)$, transpiration $(E)$ and stomatal conductance $\left(g_{s}\right)$ measurements in years of 2013, 2014 and 2015. NLS, HLS, and FLS represent none lateral shoots (no leaf), half lateral shoots (3-4 leaves) full lateral shoots (6-7 leaves). $1 \mathrm{~m}, 1.25 \mathrm{~m}$ and $1.5 \mathrm{~m}$ also represent main shoot lengths

In many literature examining the relationship between photosynthesis (A), transpiration (E), stoma conductivity $\left(\mathrm{g}_{\mathrm{s}}\right.$ ) (Motzer et al., 2005; Miyashita et al., 2005; Greer, 2012) and in the previous year measurements at the same vineyard (Candar et al., 2017), high correlation between stoma conductivity ( $\left.\mathrm{g}_{\mathrm{s}}\right)$, photosynthesis (A) and transpiration (E) in other varieties and grapevines was also observed in 2013 measurements. The highest values in the measurements made after completion of canopy interventions were seen in NLS and $1.25 \mathrm{~m}$ applications.

In 2014 when the photosynthesis averages of the measurement days are evaluated as a whole without leaving the treatments, it is seen that the measurements taken on $181^{\text {st }}$ calendar day of 2014 have a higher rate of photosynthesis than the other days with 
$12.05 \mu \mathrm{mol} \mathrm{CO}_{2} \mathrm{~m}^{-2} \mathrm{~s}^{-1}$ ratio. In the meso-climatic measurements made between 10:00-12:00 on the same day, the average temperature was $23.30^{\circ} \mathrm{C}$, the highest temperature was $26.50^{\circ} \mathrm{C}$ and the lowest temperature was $18.20^{\circ} \mathrm{C}$. The average wind speed was $2.10 \mathrm{~m} \mathrm{sec}^{-1}$ and relative humidity was $78 \%$, while the light intensity was $723.24 \mu \mathrm{mol} \mathrm{m} \mathrm{m}^{2} / \mathrm{sec}$. The lowest photosynthesis rate for all days in 2014 was measured as $7.76 \mu \mathrm{mol} \mathrm{CO} 2 \mathrm{~m}^{-2} \mathrm{~s}^{-1}$ on $195^{\text {th }}$ calendar day of 2014 . On $195^{\text {th }}$ calendar day of 2014 the maximum air temperature was $30.20^{\circ} \mathrm{C}$ and the relative humidity $73.00 \%$. Light intensity recorded at $725.67 \mu \mathrm{mol} \mathrm{m} \mathrm{m} \mathrm{sec}^{-1}$. The lowest photosynthesis rate for all days was measured as $7.76 \mu \mathrm{mol} \mathrm{CO} 2 \mathrm{~m}^{-2} \mathrm{~s}^{-1}$ on $195^{\text {th }}$ calendar day of 2014 . On the same calendar day maximum air temperature was $30.20^{\circ} \mathrm{C}$ and the relative humidity $73.00 \%$. Light intensity recorded at $725.67 \mu \mathrm{mol} \mathrm{m} / \mathrm{sec}^{-1}$.

In 2014, NLS was the first in 3 of 7 days and in 4 days, it was seen that the second place. When the measurement days are evaluated together. NLS application stands out with the highest photosynthesis rate with the average of $11.16 \mu \mathrm{mol} \mathrm{CO} 2 \mathrm{~m}^{-2} \mathrm{~s}^{-1}$.

Transpiration (E) measurements in 2014 recorded less than zero results in six of the seven measurement days. Although this situation is not encountered in the literature in terms of vine varieties, it is seen in the studies made for perennial woody plants (Vesala et al., 2017).

In terms of the monitored climate characteristics, the average, low and high temperature values at $2 \mathrm{~m}$ level for 2014 and 2015 are very close to each other; the relative humidity is $72.33 \%$ in 2014 and $73.36 \%$ in 2015 ; It can be said that the subzero transpiration values in 2014 were due to the average wind speed of $2.78 \mathrm{~m} \mathrm{~s}^{-1}$ and the light intensity values measured as $1191.955 \mathrm{~mol} \mathrm{~m}^{2} \mathrm{~s}^{-1}$ which is slow than 2015 .

Escalona et al. (2013) reported that water vapor can condense on the leaf surface and enter through the stoma openings, especially on humid nights where the vapor pressure difference is very low in coastal areas. This prevents transpiration at night and therefore reduces water loss and increases the water usage efficiency of the next day.

As expected, stoma conductivity $\left(\mathrm{g}_{\mathrm{s}}\right)$ values are also largely negative measurements. When stoma conductivity $\left(\mathrm{g}_{\mathrm{s}}\right)$ measurements are examined by subjects, it is seen that there are no significant differences between applications. However, the variation between the measurements is higher than the transpiration $(\mathrm{E})$ values.

Both transpiration $(\mathrm{E})$ and stoma conductivity $\left(\mathrm{g}_{\mathrm{s}}\right)$ produce similar curves. In terms of shoot length applications, $1.25 \mathrm{~m}$ application showed high values in vegetation average, albeit with very small differences. The main factor controlling these physiological variables appears to be meso-climatic conditions rather than applications. However, the cumulative effect of small canopy management manipulations becomes more significant when evaluated throughout phenological periods or when the all vegetation period is evaluated as whole.

When photosynthesis (A), transpiration (E) and stoma conductance $\left(\mathrm{g}_{\mathrm{s}}\right)$ measurements were evaluated on the basis of applications, although there were no significant differences between the applications, the removal of the entire lateral shoots in 2014 positively affected the vine microclimate in terms of these criteria.

Figure 1 shows the measurement values of 2015 photosynthesis (A). When the averages of the measurement days are evaluated as a whole without separating the applications, it is seen that the measurements made on $187^{\text {th }}$ calendar day of 2015 have a higher rate of photosynthesis than the other days with a ratio of $17.63 \mu \mathrm{mol}$ $\mathrm{CO}_{2} \mathrm{~m}^{-2} \mathrm{~s}^{-1}$. On the same calendar day between 10:00-14:00 meso-climatic measurements mean temperature of $24.60^{\circ} \mathrm{C}$; The highest temperature was $29.50^{\circ} \mathrm{C}$ and 
the lowest temperature was $18.40^{\circ} \mathrm{C}$. The average wind speed was $2.30 \mathrm{~m} \mathrm{sec}^{-1}$ and relative humidity was recorded as $70.10 \%$, while the illumination intensity is $1902.26 \mu \mathrm{mol} \mathrm{m} \mathrm{m}^{2} \mathrm{~s}^{-1}$. The lowest photosynthesis rate for all days on 02.10 .2015 was measured as $6.40 \mu \mathrm{mol} \mathrm{CO} \mathrm{Cm}^{-2} \mathrm{~s}^{-1}$. On $274^{\text {th }}$ calendar day of 2015 , the maximum air temperature was $19.90^{\circ} \mathrm{C}$ and the relative humidity was $77.30 \%$. Light intensity was recorded as $44.37 \mu \mathrm{mol} \mathrm{m} \mathrm{m}^{-1}$.

In terms of photosynthesis values, HLS was in the first place in 5 of 9 days in 2015; and in the second place in 2 days. When all measurement days average is evaluated together, this time. FLS application has the highest photosynthesis rate, with a small difference of $12.70 \mu \mathrm{mol} \mathrm{CO} 2 \mathrm{~m}^{-2} \mathrm{~s}^{-1}$.

The highest transpiration (E) value in all days in 2015 was measured as $2.15 \mathrm{mmol} \mathrm{m} \mathrm{m}^{-2} \mathrm{~s}^{-1}$ under the average temperature of $24.60^{\circ} \mathrm{C}$, average wind speed of $2.30 \mathrm{~m} \mathrm{~s}^{-1}, 70.10 \%$ relative humidity and $1902.26 \mu \mathrm{mol} \mathrm{m}^{2} \mathrm{~s}^{-1}$ light intensity conditions.

Furthermore, the lowest transpiration (E) value was measured as $-0.18 \mathrm{mmol} \mathrm{m}^{-2} \mathrm{~s}^{-1}$ on $215^{\text {th }}$ calendar day of 2015 . Today's average temperature was $30.20^{\circ} \mathrm{C}$ and the relative humidity was $76.20 \%$. The average wind speed was recorded as $2.20 \mathrm{~m} \mathrm{~s}^{-1}$.

Although some researchers report that transpiration decreases due to wind speed (Kuiper, 1961; Drake et al., 1970; Dixon and Grace, 1984). General acceptance, evaporation also increased due to the increasing wind speed that increased atmospheric evaporative demand (Mcvicar et al., 2012; Ben Neriah et al., 2014; Schymanski and Or, 2015).

In terms of general application averages, the highest transpiration rate was $1.49 \mathrm{mmol} \mathrm{m}^{-2} \mathrm{~s}^{-1}$ with NLS application which all lateral leaves were taken.

When stoma conductivity $\left(\mathrm{g}_{\mathrm{s}}\right)$ measurements of 2015 are examined according to the subjects, it is seen that there are no significant differences between the applications and create similar curves with transpiration $(\mathrm{E})$.

Greer (2012) reported that transpiration is strongly related to temperature. It is stated that the rates increase exponentially, especially at temperatures above $35^{\circ} \mathrm{C}$, and it is 4 times more than $20^{\circ} \mathrm{C}$ at $45^{\circ} \mathrm{C}$. In our study, when the data for 3 years are examined, it can be said that the relative humidity above $75 \%$ decreases the transpiration and increases between $65-70 \%$ the relative humidity.

Many studies on grapevine have focused on seeking answers to questions about water use efficiency through photosynthesis (A), transpiration (E), and stoma conductivity $\left(\mathrm{g}_{\mathrm{s}}\right)$ by different levels of drought stress (Bota et al., 2001; Flexas et al., 2002; Souza et al., 2003; Pou et al., 2008; Zsófi et al., 2009), variety differences (Gibberd et al., 2001; Gaudillère et al., 2002; Tomás et al., 2012) and the effects of rootstocks (Satisha et al., 2006). However, attempting to interpret results over total biomass is problematic due to measurements made from a single leaf.

Photosynthesis is the source of carbohydrate gain in plants; transpiration is also the biggest source of water losses under normal conditions. Discrepancies between WUE leaf and WUE plant may occur due to water losses during the night and daily carbon losses through respiration (Flexas et al., 2010; Schultz and Stoll, 2010).

\section{Must composition and berry maturation}

In terms of total soluble solids (TSS) content NLS treatment differs from other lateral shoot applications every 3 years. While the lowest data were obtained from this application with $21.18 \%$ in 2013 and $22.42 \%$ in 2015, the highest TSS content was observed in 2014 with $21.31 \%$ (Table 5). 
Table 5. Effects of main shoot and lateral shoot treatments on total soluble solids and total acidity

\begin{tabular}{|c|c|c|c|c|c|c|c|c|}
\hline & \multicolumn{2}{|c|}{2013} & \multicolumn{2}{|c|}{2014} & \multicolumn{2}{|c|}{2015} & \multicolumn{2}{|c|}{ Mean of years } \\
\hline Treatments & $\begin{array}{l}\text { TSS } \\
(\%)\end{array}$ & $\begin{array}{l}\text { Total acid } \\
(\mathrm{g} / \mathrm{L})\end{array}$ & $\begin{array}{l}\text { TSS } \\
(\%)\end{array}$ & $\begin{array}{c}\text { Total acid } \\
(\mathrm{g} / \mathrm{L})\end{array}$ & $\begin{array}{l}\text { TSS } \\
(\%)\end{array}$ & $\begin{array}{c}\text { Total acid } \\
(\mathrm{g} / \mathrm{L})\end{array}$ & $\begin{array}{l}\text { TSS } \\
(\%)\end{array}$ & $\begin{array}{c}\text { Total acid } \\
\text { (g/L) }\end{array}$ \\
\hline $1 \mathrm{~m}$ & $21.90 c$ & 5.85 & 20.97 & 7.45 & 22.42 & 5.85 & $21.76 b$ & 6.38 \\
\hline $1.25 \mathrm{~m}$ & $22.23 b$ & 5.83 & 20.97 & 7.53 & 22.80 & 5.83 & $22.00 a$ & 6.40 \\
\hline $1.5 \mathrm{~m}$ & $22.56 a$ & 5.93 & 20.86 & 7.56 & 22.75 & 5.90 & $22.06 a$ & 6.46 \\
\hline NLS & $21.18 b$ & 5.96 & $21.31 a$ & $7.13 b$ & $22.42 b$ & 5.78 & $21.64 b$ & 6.29 \\
\hline HLS & $22.65 a$ & 5.85 & $20.84 b$ & $7.61 a$ & $22.86 a$ & 5.86 & $22.12 a$ & 6.42 \\
\hline FLS & $22.85 a$ & 5.80 & $20.66 b$ & $7.80 a$ & $22.68 a b$ & 5.93 & $22.07 a$ & 6.52 \\
\hline YME & $22.28 B$ & $5.87 \mathrm{~B}$ & $20.94 C$ & $7.51 A$ & $22.65 A$ & $5.86 B$ & & \\
\hline MSME LSD 0.05 & 0.299 & n.s. & n.s. & n.s. & n.s. & n.s. & 0.209 & n.s. \\
\hline LSME LSD 0.05 & 0.629 & n.s. & 0.383 & 0.273 & 0.343 & n.s. & 0.342 & n.s. \\
\hline$Y M E L S D 0.05$ & 0.342 & 0.378 & 0.342 & 0.378 & 0.342 & 0.378 & & \\
\hline
\end{tabular}

NLS, HLS, and FLS represent none lateral shoots (no leaf), half lateral shoots (3-4 leaves) full lateral shoots (6-7 leaves), MSME means main shoot main effect, LSME means lateral shoot main effect and YME means year main effect. Different lowercase superscript letters in same column and uppercase letters in same line represent statistically significant differences between means at $p<0.05$ according to least significant difference test. n.s. means not significant

As NLS application stands out with the highest photosynthesis rate in 2014, during the vegetation period, excessive precipitation and high proportional humidity conditions positively affected the physiological activity of the NLS application and accelerated the photosynthetic efficiency and thus the accumulation of dry matter. Therefore, it was seen that the effects of negative climate characteristics can be reduced by manipulations on the canopy at the right time and in the right way.

The results obtained in 2013 and 2015 suggest that increased photosynthesis rates in HLS application also increase the accumulation of TSS.

Korkutal et al. (2017) reported that the complete removal of the lateral leaves increases the total acidity. In our study, the same results were observed in NLS application in 2013, but it was seen in 2014 and 2015 and the mean of all years caused lower total acidity (Table 5).

One of the most significant relationships between temperature and berry quality is that high temperatures reduce the concentration of organic acid in the berry (Kliewer, 1973). Organic acid accumulation and degradation at different stages of berry development also show different characteristics (Ford, 2012). Tartaric and malic acids are predominant organic acids in all stages of berry maturation and cause significant effects on must acidity and $\mathrm{pH}$ (Morris et al., 1983). In particular, malate is deposited in the berry until the veraison and stored as a potential source for the carbon requirement that occurs during the ripening process (Ruffner, 1982). During this period, the reduction of total acidity due to consumed malic acid balances sugar and acid ratios (Kliewer, 1965).

A similar situation was observed in 2013, NLS application reduced the usefulness of photosynthesis, thus reducing the use of malic acid as a carbon source and the total acidity remained high. Apart from this, no statistical significance was found between the applications and total acidity level for the mean of years. On the other hand, the increase in the length of the main shoot caused an increase of titratable acid in the average of years, but not statistically. Likewise, according to Yasasin et al. (2018), the 
increase in main shoot length causes a decrease in total acidity, although this is not statistically significant.

$\mathrm{pH}$ is a measure of active acidity in must and wine. Therefore. there is a dynamic relationship between $\mathrm{pH}$ and acidity. The $\mathrm{pH}$ of grape must be one of the critical determinants of wine quality. The exchange of tartaric acid compounds with potassium cations produces water-insoluble potassium bi-tartrates. This leads to a reduction of free acids and tartaric/malic acid ratios and an increase in $\mathrm{pH}$ (Kodur, 2011).

In our study, $\mathrm{pH}$ values increased in 2013 and 2014 with the decrease of leaf area under the main effect of lateral shoot applications. This change in 2014 is also statistically significant. Although this relationship between manipulations and $\mathrm{pH}$ did not occur in the mean of years, it is important to reflect the relationship between variables such as titratable acidity, potassium and the amount of precipitation to which they depend. Lateral shoot manipulations have a statistically significant effect on the amount of sugar per gram every 3 years. The NLS application reached its highest value in 2014 and took the last place in the other years (Table 6).

Table 6. Effects of main shoot and lateral shoot treatments on $\mathrm{pH}$ and sugar

\begin{tabular}{|c|c|c|c|c|c|c|c|c|}
\hline & \multicolumn{2}{|r|}{2013} & \multicolumn{2}{|r|}{2014} & \multicolumn{2}{|r|}{2015} & \multicolumn{2}{|c|}{ Mean of years } \\
\hline Treatments & pH & $\begin{array}{c}\text { Sugar } \\
\left(\mathrm{mg} \mathrm{g-berry}^{-1}\right)\end{array}$ & pH & $\begin{array}{c}\text { Sugar } \\
\left(\mathrm{mg} \mathrm{g-berry}^{-1}\right)\end{array}$ & pH & $\begin{array}{c}\text { Sugar } \\
\left(\text { mg g-berry }^{-1}\right)\end{array}$ & pH & $\begin{array}{c}\text { Sugar } \\
\left(\mathrm{mg} \mathrm{g-berry}^{-1}\right)\end{array}$ \\
\hline $1 \mathrm{~m}$ & 3.85 & $164.41 c$ & 3.54 & 156.22 & 3.75 & 169.00 & 3.71 & $163.21 b$ \\
\hline $1.25 \mathrm{~m}$ & 3.74 & $167.35 b$ & 3.54 & 156.22 & 3.73 & 172.40 & 3.67 & $165.32 a$ \\
\hline $1.5 \mathrm{~m}$ & 3.79 & $170.29 a$ & 3.53 & 155.26 & 3.77 & 171.99 & 3.70 & $165.84 a$ \\
\hline NLS & 3.90 & $158.11 b$ & $3.58 a$ & $159.15 a$ & 3.75 & $169.03 b$ & 3.74 & $162.09 b$ \\
\hline HLS & 3.84 & $171.10 a$ & $3.54 b$ & $155.05 b$ & 3.75 & $172.96 a$ & 3.65 & $166.37 a$ \\
\hline FLS & 3.65 & $172.85 a$ & $3.50 c$ & $153.48 b$ & 3.75 & $171.40 a b$ & 3.70 & $165.91 a$ \\
\hline YME & $3.79 A$ & $167.35 \mathrm{~A}$ & $3.54 B$ & $155.90 C$ & $3.75 A$ & $171.13 A$ & & \\
\hline$M_{\text {MSME LSD }} 0.05$ & $n . s$. & 5.615 & $n . s$. & 3.386 & n.s. & 3.076 & n.s. & 3.035 \\
\hline LSME LSD 0.05 & n.s. & 2.659 & 0.034 & n.s. & n.s. & n.s. & n.s. & 1.866 \\
\hline$Y M E L S D_{0.05}$ & 0.197 & 3.035 & 0.197 & 3.035 & 0.197 & 3.035 & & \\
\hline
\end{tabular}

NLS, HLS, and FLS represent none lateral shoots (no leaf), half lateral shoots (3-4 leaves) full lateral shoots (6-7 leaves), MSME means main shoot main effect, LSME means lateral shoot main effect and YME means year main effect. Different lowercase superscript letters in same column and uppercase letters in same line represent statistically significant differences between means at $p<0.05$ according to least significant difference test, n.s. means not significant

The ideal ${ }^{\circ}$ Brix/titratable acid ratio range was expressed as 3-4 $\mathrm{g} \mathrm{L}^{-1}$ by Blouin and Guimberteau (2000). Except for 2014, these values were observed in other years and in different main and lateral shoot applications. 2013 and 2015 were the years with the highest ${ }^{\circ}$ Brix/titratable acid ratios of $3.87 \mathrm{~g} \mathrm{~L}^{-1}$ and $3.82 \mathrm{~g} \mathrm{~L}^{-1}$. In $2014{ }^{\circ}$ Brix/titratable acid ratio was calculated as $2.79 \mathrm{~g} \mathrm{~L}^{-1}$. The mean of years was statistically significant at LSD level of 5\%. The main effects of lateral and main shoot applications were not statistically significant except for 2014. In 2014, the NLS application differs from HLS and FLS (Table 7).

The mean of years was statistically significant at LSD level of $5 \%$ for $\mathrm{pH}^{2} \times{ }^{\circ} \mathrm{Brix}$, maturity index. However, the main effects of the applications in 2014 were statistically significant and it is seen that NLS application has brought maturity to an early stage when compared to other two. In 2014, the $\mathrm{pH}^{2} \times{ }^{\circ}$ Brix was calculated as 262.98 .

According to the maturity index of $\mathrm{pH}^{2} \times{ }^{\circ} \mathrm{Brix}$, berries over 260 reach full maturity (Blouin and Guimberteau, 2000). According to this indicator, maturity was reached 
every three years and in all applications. The difference between the applications is low and statistically insignificant, but it is determined that small changes in maturity level can be created with different canopy management techniques.

Table 7. Effects of main shoot and lateral shoot treatments on maturity indices

\begin{tabular}{|c|c|c|c|c|c|c|c|c|}
\hline & \multicolumn{2}{|c|}{2013} & \multicolumn{2}{|c|}{2014} & \multicolumn{2}{|c|}{2015} & \multicolumn{2}{|c|}{ Mean of years } \\
\hline Treatments & $\begin{array}{c}{ }^{\circ} \text { Brix/ } \\
\text { T.A } \\
\end{array}$ & $\mathbf{p H}^{2} \times{ }^{\circ}$ Brix & $\begin{array}{c}{ }^{\circ} \text { Brix/ } \\
\text { T.A } \\
\end{array}$ & $\mathbf{p H}^{2} \times{ }^{\circ}$ Brix & $\begin{array}{c}{ }^{\circ} \text { Brix/ } \\
\text { T.A } \\
\end{array}$ & $\mathbf{p H}^{2} \times{ }^{\circ}$ Brix & $\begin{array}{c}{ }^{\circ} \text { Brix/ } \\
\text { T.A }\end{array}$ & $\mathbf{p H}^{2} \times{ }^{\circ}$ Brix \\
\hline $1 \mathrm{~m}$ & 3.78 & 324.63 & 2.82 & 264.38 & 3.83 & 310.01 & 3.48 & 301.67 \\
\hline $1.25 \mathrm{~m}$ & 3.86 & 316.05 & 2.79 & 263.26 & 3.91 & 317.99 & 3.52 & 299.10 \\
\hline $1.5 \mathrm{~m}$ & 3.82 & 327.16 & 2.76 & 261.31 & 3.86 & 324.53 & 3.48 & 304.33 \\
\hline NLS & 3.57 & 323.85 & $2.98 a$ & $273.52 a$ & 3.88 & 315.78 & 3.48 & 304.38 \\
\hline HLS & 3.94 & 302.45 & $2.74 b$ & $261.91 b$ & 3.90 & 322.52 & 3.53 & 295.63 \\
\hline FLS & 3.94 & 341.54 & $2.65 b$ & $253.52 c$ & 3.83 & 320.22 & 3.47 & 305.09 \\
\hline YME & $3.82 A$ & $322.61 \mathrm{~A}$ & $2.79 B$ & $262.98 \mathrm{~B}$ & $3.87 A$ & $319.51 \mathrm{~A}$ & & \\
\hline MSME LSD 0.05 & n.s. & n.s. & n.s. & n.s. & n.s. & n.s. & n.s. & n.s. \\
\hline LSME LSD 0.05 & n.s. & $n . s$. & 0.121 & 8.036 & n.s. & n.s. & n.s. & n.s. \\
\hline$Y M E L S D_{0.05}$ & 0.272 & 33.184 & 0.272 & 33.184 & 0.272 & 33.184 & & \\
\hline
\end{tabular}

NLS, HLS, and FLS represent none lateral shoots (no leaf), half lateral shoots (3-4 leaves) full lateral shoots (6-7 leaves), MSME means main shoot main effect, LSME means lateral shoot main effect and YME means year main effect, T.A. Titratable acid, Different lowercase superscript letters in same column and uppercase letters in same line represent statistically significant differences between means at $p<0.05$ according to least significant difference test, n.s. means not significant

\section{Conclusion}

When photosynthesis (A), transpiration (E) and stoma conductivity ( $\left.\mathrm{g}_{\mathrm{s}}\right)$ measurements were evaluated together with the climatic conditions of lateral shoot applications; It can be said that the significant differences between the applications are mostly seen in the criteria of average light intensity, relative humidity and average wind speed on some days.

In this sense, the main factor controlling these physiological variables appears to be the meso-climatic climatic conditions. However, the cumulative effect of small microclimatic differences becomes more significant when compared to phenological periods or when the vegetation period is evaluated as a whole.

Relative humidity is more effective than temperature in terms of physiological activity. It can be said that proportional humidity above $75 \%$ decreases transpiration and increases proportional humidity between $65-70 \%$. The potential importance of nighttime transpiration and the interaction of water use efficiency with regard to plant quality are emerging as new research topics.

It can be said that keeping the leaf areas under control in order to provide sufficient yield/quality balance under the conditions which the experiment is carried out may be a solution. Even in cases where leaf areas are reduced more than normal, there is no shortage of the desired yield with delay in industrial maturity.

Therefore, it is considered that the decrease in leaf areas can be compensated for in terms of yield by arrangements in the internal metabolism of the vine. This shows that unusual canopy management practices that can be performed against unusual climatic conditions (high proportional humidity, high temperature fluctuations, heavy rainy periods, etc.) can be used at certain periods even if not every year. 
It is seen that NLS application is separated from the others in total soluble solids content every 3 years. While the lowest data were obtained from this application with $21.18 \%$ in 2013 and $22.42 \%$. In 2015, the highest TSS was observed in 2014 with $21.31 \%$. In 2014, excessive rainfall and high proportional humidity during the vegetation period positively affected the physiological activity of NLS vines, accelerating the efficiency of photosynthesis and thus the accumulation of dry matter throughout the vine.

In terms of the main shoot lengths, as the shoot length increases, stress and some quality criteria tend to increase, but these effects are generally not statistically significant. Even when the main shoot length is kept at $1 \mathrm{~m}$, leaf areas can reach a sufficient level in terms of yield and quality.

Although the applications are effective in terms of quality and physiological activity, seasonal effects of each vegetation period are the main determining factors.

Acknowledgements. This study is based on a part of the doctoral thesis of the corresponding author and supported by Republic of Turkey Ministry of Agriculture and Forestry General Directorate of Agricultural Research and Policies with the project number TAGEM / BBAD / 2013 / A08 / P04-08.

\section{REFERENCES}

[1] Bem, B. P., Bogo, A., Everhart, S. E., Casa, R. T., Gonçalvales, M. J., Macron Filho, J. L., Rufato, L., Silva, F. N., Allebrandt, R., Cunha, I. C. (2016): Effect of four training systems on the temporal dynamics of downy mildew in two grapevine cultivars in Southern Brazil. - Tropical Plant Pathology 41: 370-379. doi.org/10.1007/s40858-0160110-8.

[2] Ben Neriah, A., Assouline, S., Shavit, U., Weisbrod, N. (2014): Impact of ambient conditions on evaporation from porous media. - Water Resources Research 50(8): 66966712. doi.org/10.1002/2014WR015523.

[3] Blouin, J., Guimberteau, G. (2000): Maturation et Maturite des Raisins. - Feret. Bordeaux. 151 p. ISBN: 2-902416-49-0.

[4] Bota, J., Flexas, J., Medrano, H. (2001): Genetic variability of photosynthesis and water use in Balearic grapevine cultivars. - Annals of Applied Biology 138(3): 353-361. doi.org/10.1111/j.1744-7348.2001.tb00120.x.

[5] Caccavello, G., Giaccone, M., Scognamiglio, P., Forlani, M., Basile, B. (2017): Influence of intensity of post-veraison defoliation or shoot trimming on vine physiology, yield components, berry and wine composition in Aglianico grapevines. - Australian Journal of Grape and Wine Research 23: 226-239. doi.org/10.1111/ajgw.12263.

[6] Candar, S., Yasasin, A. S., Alco, T., Bahar, E., Korkutal, I. (2017): Interactions of Some Environmental Factors on Physiological Parameters in cv. Merlot (Vitis vinifera L.). $-2^{\text {nd }}$ International Balkan Agriculture Congress 16-18 May 2017. Abstract Book, pp: 328. Tekirdag.

[7] Carbonneau, A., Bahar, E. (2009): Vine and Berry Responses to Contrasted Water Fluxes in Ecotron Around 'Veraison'. Manipulation of Berry Shrivelling and Consequences on Berry Growth. Sugar Loading and Maturation. - Proceedings of the $16^{\text {th }}$ International GiESCO Symposium. July 12-15. Univ. of California. Davis, pp. 145-155.

[8] Clingeleffer, P. R. (2010): Plant management research: status and what it can offer to address challenges and limitations. - Australian Journal of Grape and Wine Research 16(1): 25-32. doi.org/10.1111/j.1755-0238.2009.00075.x. 
[9] Collins, M., Loveys, B. (2010): Optimizing irrigation for different cultivars. - Final Report to Grape and Wine Research \& Development Corporation, Project Number: CSP 05/02. CSIRO Plant Industry.

[10] Dixon, M., Grace, J. (1984): Effect of wind on the transpiration of young trees. - Annals of Botany 53(6): 811-819. doi.org/10.1093/oxfordjournals.aob.a086751.

[11] Drake, B. G., Raschke, K., Salisbury, F. B. (1970): Temperature and transpiration resistances of Xanthium leaves as affected by air temperature, humidity, and wind speed. - Plant Physiology 46: 324-330. doi.org/10.1104/pp.46.2.324.

[12] Escalona, J., Fuentes, S., Tomas, M., Martorella, S., Flexas, J., Medrano, H. (2013): Responses of leaf night transpiration to drought stress in Vitis vinifera L. - Agricultural Water Management 118: 50-58. doi.org/10.1016/j.agwat.2012.11.018.

[13] Ferrer, M., Echeverría, G., Carbonneau, A. (2014): Effect of berry weight and its components on the contents of sugars and anthocyanins of three varieties of Vitis vinifera L. under different water supply conditions. - South African Journal of Enology and Viticulture 35(1): 103-113.

[14] Flexas, J., Medrano, H., Escalona, J. M., Bota, J., Gulias, J. (2002): Regulation of photosynthesis of $\mathrm{C} 3$ plants in response to progressive drought: Stomatal conductance as a reference parameter. - Annals of Botany 89(7): 895-905. doi.org/10.1093/aob/mcf079.

[15] Flexas, J., Galmés, J., Gallé, A., Gulías, J., Pou, A., Ribas-Carbo, M., Tomás, M., Medrano, H. (2010): Improving water use efficiency in grapevines: Potential physiological targets for biotechnological improvement. - Australian Journal Grape Wine Research 16(1s): 106-121. doi.org/10.1111/j..1755-0238.2009.00057.x.

[16] Ford, C. M. (2012): The Biochemistry of Organic Acids in the Grape. The Biochemistry of the Grape Berry. - Bentham Science Publishers, 67-88. doi: 10.2174/978160805360511201010067.

[17] Gaudillère, J. P., van Leeuwen, C., Ollat, N. (2002): Carbon isotope composition of sugars in grapevine and integrated indicator of vineyard water status. - Journal of Experimental Botany 53(369): 757-763. doi.org/10.1093/jexbot/53.369.757.

[18] Gibberd, M. R., Walker, R. R., Blackmore, D. H., Condon, A. G. (2001): Transpiration efficiency and carbon-isotope discrimination of grapevines grown under well-watered conditions in either glasshouse or vineyard. - Australian Journal Grape and Wine Research 7(3): 110-117. doi.org/10.1111/j.1755-0238.2001.tb00197.x.

[19] Greer, D. H. (2012): Modelling leaf photosynthetic and transpiration temperature dependent responses in Vitis vinifera cv. Semillon grapevines growing in hot, irrigated vineyard conditions. - AoB Plants pls009. doi: 10.1093/aobpla/pls009.

[20] Hirano, K., Noda, M., Hasegawa, S., Okamota, G. (1994): Contribution of lateral and primary leaves to the development and quality of Kyoho grape berry. - Journal of Japan Society Horticultural Science 63(3): 515-521. doi.org/10.2503/jjshs.63.515.

[21] Keller, M. (2010a): Managing grapevines to optimise fruit development in a challenging environment: a climate change primer for viticulturists. - Australian Journal of Grape and Wine Research 16: 56-69. doi:10.1111/j.1755 0238.2009.00077.x.

[22] Keller, M. (2010b): The Science of Grapevines: Anatomy and Physiology $1^{\text {st }}$ Edition. Academic Press, 400 p. ISBN: 9780123748812.

[23] Kliewer, W. M. (1965): Changes in the concentration of malates. tartrates. and total free acids in flowers and berries of Vitis vinifera. - American Journal of Enology and Viticulture 16: 92-100.

[24] Kliewer, W. M. (1973): Berry composition of Vitis vinifera cultivars as influenced by photo temperatures and nycto-temperatures during maturation. - Journal of the American Society for Horticultural Science 98: 153-159.

[25] Kodur, S. (2011): Effects of juice $\mathrm{pH}$ and potassium on juice and wine quality. and regulation of potassium in grapevines through rootstocks (Vitis): a short review. - Vitis 50(1): $1-6$. 
[26] Korkutal, İ., Bahar, E., Bayram, S. (2017): Farklı toprak işleme ve yaprak alma uygulamalarının Syrah üzüm çeşidinde su stresi. salkım ve tane özellikleri üzerine etkileri. - Ege Üniversitesi, Ziraat Fakültesi Dergisi 54(4): 397-407.

[27] Kuiper, P. (1961): The Effects of Environmental Factors on the Transpiration of Leaves, With Special Reference to Stomatal Light Response. - Ph.D. Thesis. Veenman, Wageningen, Proefschriftwageningen.

[28] McVicar, T. R., Roderick, M. L., Donohue, R. J., Li, L. T., Van Nieli T. G., Thomas, A. (2012): Global review and synthesis of trends in observed terrestrial near-surface wind speeds: Implications for evaporation. - Journal of Hydrology 416-417: 182-205. doi.org/10.1016/j.jhydrol.2011.10.024.

[29] Mira de Orduña, R. (2010): Climate change associated effects on grape and wine quality and production. - Food Research International 43(7): 1844-1855. doi.org/10.1016/j.foodres.2010.05.001.

[30] Miyashita, K., Shigemi, T., Toshihiko, M., Kazuyoshi, K. (2005): Recovery responses of photosynthesis. transpiration and stomatal conductance in kidney bean following drought stress. - Environmental and Experimental Botany 53(2): 205-214. doi: 10.1016/j.envexpbot.2004.03.015.

[31] Moran, M. A., Sadras, V. O., Petrie, P. R. (2017): Late pruning and carry-over effects on phenology. yield components and berry traits in Shiraz. - Australian Journal of Grape and Wine Research 23(3): 390-398. doi.org/10.1111/ajgw.12298.

[32] Morris, J. R., Sims, C. A., Cawthon, D. L. (1983): Effects of excessive potassium levels on $\mathrm{pH}$. acidity and color of fresh and stored grape juice. - American Journal of Enology and Viticulture 34(1): 35-39.

[33] Motzer, T., Nicole, M., Manfred, K., Dieter, S., Dieter, A. (2005): Stomatal conductance, transpiration and sap flow of tropical Montane rain forest trees in the Southern Ecuadorian Andes. - $\quad$ Tree Physiology 25(10): 1283-1293. doi.org/10.1093/treephys/25.10.1283.

[34] OIV (2012): Compendium of International Methods of Wine and Musts. - Ed. 2012. v: 12.

[35] Petrie, P., Sadras, V. (2008): Advancement of grapevine maturity in Australia between 1993 and 2006: putative causes. magnitude of trends and viticultural consequences. Australian Journal of Grape and Wine Research 14: 33-45. doi:10.1111/j.17550238.2008.00005.x.

[36] Poni, S., Gatti, M., Bernizzoni, F., Civardi, S., Bobeica, N., Magnanini, E., Palliotti, A. (2013): Late leaf removal aimed at delaying ripening in cv. Sangiovese: physiological assessment and vine performance. - Australian Journal of Grape and Wine Research 19(3): 378-387. doi.org/10.1111/ajgw.12040.

[37] Pou, A., Flexas, J., Alsina, M., Bota, J., Carambula, C., Herralde, F., Galmes, J., Lovisolo, C., Jimenez, M., Carbo, M. R., Rusjan, D., Secchi, F., Tomas, M., Zsófi, Z., Medrano, H. (2008): Adjustments of water use efficiency by stomatal regulation during drought and recovery in the drought-adapted Vitis hybrid Richter-110 (V. berlandieri $x$ V. rupestris). - Physiologia Plantarum 134(2): 313-323. doi: 10.1111/j.13993054.2008.01138.x.

[38] Ruffner, H. P. (1982): Metabolism of tartaric and malic acids in Vitis-A review. - Vitis 21: 346-358.

[39] Sanchez-de-Miguel, P., Bazea, P., Junquera, P., Lissarrague, J. R. (2010): Vegetative Development: Total Leaf Area and Surface Area Indexes. - In: Delrot, S., Medrano, H., Or, E., Bavaresco, L., Grando, S. (eds.) Methodologies and Results in Grapevine Research. Springer Science. 448 p. ISBN: 904819282X.

[40] Santesteban, L. G., Miranda, C., Royo, J. B. (2011): Regulated deficit irrigation effects on growth, yield, grape quality and individual anthocyanin composition in Vitis vinifera $\mathrm{L}$. cv.'Tempranillo'. - Agricultural Water Management 98(7): 1171-1179. 
[41] Satisha, J., Prakash, G. S., Venugopalan, R. (2006): Statistical modeling of the effect of physio-biochemical parameters on water use efficiency of grape cultivars. rootstocks and their stionic combinations under moisture stress conditions. - Turkish Journal of Agriculture and Forestry 30(4): 261-271.

[42] Schultz, H. R., Stoll, M. (2010): Some critical issues in environmental physiology of grapevines: future challenges and current limitations. - Australian Journal of Grape and Wine Research 16: 4-24. doi:10.1111/j.1755-0238.2009.00074.x.

[43] Schymanski, S. J., Or, D. (2015): Wind increases leaf water use efficiency. - Plant, Cell \& Environment 39(7): 1448-1459. doi.org/10.1111/pce.12700.

[44] Souza, C. R., Maroco, J. P., Santos, T. P., Rodrigues, M. L., Lopes, C. M., Pereira, J. S., Chaves, M. M. (2003): Partial root zone drying: Regulation of stomatal aperture and carbon assimilation in field-grown grapevines (Vitis vinifera cv. Moscatel). - Functional Plant Biology 30: 653-662.

[45] Tomás, M., Medrano, H., Pou, A., Escalona, J. M., Martorell, S., Ribas-Carbo, M., Flexas, J. (2012): Water use efficiency in grapevine cultivars grown under controlled conditions: Effects of water stress at the leaf and whole plant level. - Australian Journal of Grape Wine Research 18(2): 164-172. doi.org/10.1111/j.1755-0238.2012.00184.x.

[46] Vesala, T., Sevanto, S., Grönholm, T., Salmon, Y., Nikinmaa, E., Hari, P., Hölttä, T. (2017): Effect of leaf water potential on internal humidity and $\mathrm{CO}_{2}$ dissolution: Reverse transpiration and improved water use efficiency under negative pressure. - Frontiers in Plant Science 6(8): 54. doi: 10.3389/Fpls.2017.00054.

[47] Yasasin, A. S., Bahar, E., Boz, Y., Kiraci, M. A., Gunduz, A., Avci, G. G., Gulcu, M. (2018): Different soil tillage and shoot length effects on vegetative growth, water stress and yield in cv. Cabernet Sauvignon (Vitis vinifera L.). - I. International Agricultural Science Congress, 9-12 May 2018, Van-Turkey, p 408.

[48] Zalamena, J., Cassol, P. C., Brunetto, G., Grohskopf, M. A., Mafra, M. S. H. (2013): Estado nutricional. vigor e produção em videiras cultivadas com plantas de cobertura. Revista Brasileira de Fruticultura 35: 1190-1200. doi: 10.1590/S010029452013000400030.

[49] Zsófi, Z., Gál, L., Szilágy, Z., Szücs, E., Marschall, M., Nagy, Z., Bál, B. (2009): Use of stomatal conductance and pre-dawn water potential to classify terroir for the grape variety Kékfrankos. - Australian Journal of Grape Wine Research 15(1): 36-47. doi.org/10.1111/j.1755-0238.2008.00036.x. 